\title{
Inventing and reinventing the modern city: the 2012 city status competition in the United Kingdom
}

\author{
JOHN BECKETT* \\ Department of History, University Park, Nottingham, NG7 2RD, UK
}

\begin{abstract}
Three new cities were created in conjunction with Her Majesty the queen's Diamond Jubilee celebrations in 2012: Chelmsford, Perth and St Asaph. They were the winners of a competition which had no clear rules, no transparency and no proper feedback. The modern style is to create new cities in conjunction with a royal event, the winners to be decided by competition. How has this come to be the case? This article looks at the 2012 competition in the light of the ways in which cities have been created in the United Kingdom since the explicit link with Anglican cathedrals was dropped in 1888, and it asks whether it is worth the effort? The author concludes that what was initially conceived as a means of distinguishing between rivals for the status of city has become a competition driven by modern forms of civic boosterism, and a blatant opportunity for political patronage by governments who hide behind royal 'privilege'. For all the effort expended, the distinction is hardly recognized outside of the town hall.
\end{abstract}

On 14 March 2012, the deputy prime minster, Nick Clegg, announced that as part of the celebrations of the queen's Diamond Jubilee three new cities were to be made, and one mayoralty was to be upgraded to lord mayor. ${ }^{1}$ This was hardly a major news item on a day when 20 children died in a serious bus crash in the Alps, and details were available only on news websites. The announcement did not make the evening television news bulletins, and it was barely reported in the following day's newspapers. This article focuses by way of background on the process of city making since the 1880s, and more fully on the 2012 competition. Two key questions are asked: why have towns been so keen to become cities, and why has the government taken the view that it has the right to exercise patronage on behalf of the monarch when it comes to the making of cities? Why, to put it another way, does the government claim the right to decide what a

* The paper originated in a keynote lecture to the 'Inventing and reinventing the modern city' international conference at Teesside University, 8 Sep. 2012. I should like to thank participants for their helpful comments.

1 www.bbc.co.uk/news/politics/ (accessed 14 Mar. 2012). 
city is, rather than allowing any town which considers itself to have the credentials of a city simply to change the sign boards?

To appreciate the position today, the development of the term 'city' needs to be understood. It is one of many terms which came to be used as a growing number of settlements exercised functions which we would recognize as urban. In Old English these places came to be known as byrig (burg, burga, burh), ceaster, port and wic, terms usually translated in Latin as urbs, civitas and portus. The most significant of these was civitas, a title the Romans used for the independent states or tribes of Gaul. It came to be used to describe the chief town of these states, and in turn towns were normally recognized as the seat of civil government and episcopal authority. ${ }^{2}$

In Domesday Book (1086) terms such as byrigan or burgi, loosely meaning borough, and civitas were used to describe places which we would recognize to be towns. More than 100 places were designated as burgi, and 13 as civitas. $^{3}$ As yet, no specific link had been established between possession of a bishopric and designation as a city. Oxford, Gloucester, Leicester, Shrewsbury and Colchester were all described as civitas, but none of these were the seats of bishops. Possibly they had been in the past: Leicester claimed to have had an Anglo-Saxon bishopric. ${ }^{4}$ The Normans pressed bishops to move to towns. The bishop for Sussex moved from Selsey to Chichester, the bishop of Sherbourne to Salisbury, Leofric, bishop of Crediton, to Exeter, and the bishop of Dorchester (Oxfordshire) to Lincoln. ${ }^{5}$

As a result of these changes, bishoprics moved in to what were considered to be important towns, and civitas was increasingly synonymous with episcopal see. ${ }^{6}$ The word cite was used in English by the thirteenth century to distinguish between ancient cities and important boroughs such as London and Lincoln. Yet, for a long time, despite urban growth, there was no obvious distinction between city, borough or a number of other contemporary terms. ${ }^{7}$ By the twelfth century, some towns were beginning to acquire formal liberties. Those known as 'borough' had rights and privileges. Between the thirteenth and seventeenth centuries, many towns acquired further privileges by virtue of new and additional charters.

The link which developed between cathedrals and towns of importance established a prima facie case to later generations for the sees of dioceses to be cities. Since no charters or other official documents were generated, cathedral towns have generally been accepted as cities by 'ancient

2 J. Beckett, City Status in the British Isles, 1830-2002 (Aldershot, 2005), 9-11.

3 S. Reynolds, Ideas and Solidarities in the Medieval Laity (Aldershot, 1995), vol. VII, 4, vol. VIII, 297-300.

${ }^{4}$ F.W. Maitland, Township and Borough (Cambridge, 1898), 42; E.A. Freeman, 'City and borough', Macmillan's Magazine, 60 (1889), 32; J. Beckett, 'Leicester becomes a city, 1919', Transactions of the Leicestershire Archaeological and Historical Society, 80 (2006), 151-62.

5 W. Hunt, The English Church: From its Foundation to the Norman Conquest (597-1066) (London, 1899), 317, 403 .

${ }^{6}$ Ibid., 38.

7 Reynolds, Ideas, vol. VI, 12. 
Table 1: English and Welsh cities by ancient prescriptive right

\begin{tabular}{lll}
\hline \hline Bath & Ely & Rochester \\
Bangor & Exeter & Salisbury \\
Canterbury & Hereford & Wells \\
Carlisle & Lichfield & Winchester \\
Chichester & Lincoln & Worcester \\
Coventry & London & York \\
Durham & Norwich & \\
\hline \hline
\end{tabular}

Source: TNA HO 286/40. The list is dated 1927.

prescriptive right'. In other words, their claim to city status is accepted because they can show that for many centuries they have been the seat of a bishop, not because anyone, at any particular time, declared they should be cities. Cathedrals were usually found in important places such as London, York, Lincoln and Durham. Other sees, including Exeter, Worcester and Hereford, were located in county towns. The majority of bishoprics were in southern England: Bath, Canterbury, Chichester, Ely, Exeter, Norwich, Rochester, Salisbury, Wells and Winchester represented the south and East Anglia; Lincoln, Lichfield, Worcester, Hereford and Coventry represented the Midlands; and York, Durham and Carlisle the north. Table 1 lists English and Welsh cities by 'ancient prescriptive right'. No Scottish or Irish towns held the title by ancient prescriptive right. ${ }^{8}$

The major distinction among towns in England was still between chartered boroughs and other places which clearly had urban functions but did not possess independent powers of government. The term 'city' did not refer to any particular legal or constitutional powers. It was used only of places which were the seats of bishops. Consequently, a city was a town with a cathedral, and a borough was a town with a charter. In the absence of any need for a town to try to improve its reputation vis-à-vis other towns, the absence of clearer definitions was not an issue.

A formal link between city and cathedral was established only in the sixteenth century. Following the Dissolution of the Monasteries, Henry VIII intended to use the windfall income from 20 large (dissolved) abbeys to create 13 bishoprics. In fact, just six dioceses were established, but each of the new cathedral towns was granted city status, Gloucester, Chester and Peterborough in 1541, ${ }^{9}$ Oxford and Bristol in 1542 and Westminster in 1540. Oxford remained a city when in 1546 the cathedral was moved

\footnotetext{
${ }^{8}$ Beckett, City Status, 11-12.

${ }_{9}$ W.H. Stevenson, Calendar of the Records of the Corporation of Gloucester (Gloucester, 1893), 10; Victoria County History (VCH) Gloucestershire, vol. IV (London, 1988), 2, 13; The National Archives (TNA) HO 45/13142.
} 
from Oseney to Christ Church. ${ }^{10}$ Westminster survived only 10 years as a diocesan see, but it continued to call itself a city.

These developments in the 1540s established two significant precedents: the right of the monarch to grant city status, and an explicit link between city status and cathedral towns. According to the first principle, towns seeking city status could petition the crown directly. Both Kilkenny in 1609 and Londonderry in 1613 applied directly to James I for grants of city status, and both were promoted. Cambridge was turned down in 1616 after opposition from the university, which feared for its own privileges. ${ }^{11}$ No further grants of city status were made directly by royal prerogative until 1994, but the precedent established by Henry VIII remains valid. Grants of city status to towns without cathedrals are still regarded as a constitutional matter. So the personal engagement of the monarch in the process is required, even if only to rubber-stamp decisions taken by her or his ministers. The second principle related city status to diocesan sees, but no new dioceses were created between the 1550s and the 1830s. ${ }^{12}$

Slightly more complicated was the case of Scotland. Aberdeen and Edinburgh were recognized as cities but the automatic link found in England between a city and a cathedral did not apply, partly because the diocesan structure common to England and Wales was not found north of the border. As a result, Scotland has no equivalent of the English concept of Ancient Prescriptive Right, although Glasgow came over time to be recognized as a city, and Perth, Dunfermline and Elgin, among others, have claimed the title. ${ }^{13}$

Industrial and urban growth from the eighteenth century meant that many towns grew in size but did not enjoy the status of cities which their importance seemed to warrant. The awkwardness is clear from Daniel Defoe's musings in his Tour through the Whole Island of Great Britain first published in the 1720s. Taunton, he noted, was 'by far the greatest [town] in all this part of the country, and has more people in it, than the city of York', while nearby Frome was 'so prodigiously increased within these last twenty or thirty years that [it] is now reckoned to have more people in it, than the city of Bath, some say, than even Salisbury itself' ${ }^{14}$ Defoe was struggling to come to terms with a distinction between city and town in which a growing and thriving place had lower status than a neighbour which maintained the position of city purely because it had a cathedral. Even more confusing was Bath: 'My description of this city would be very short', wrote Defoe, 'and indeed it would have been a very small city, (if at all a city) were it not for the hot baths here, which give both name and

${ }^{10}$ VCH Oxfordshire, vol. IV (London, 1979), 1, 74, 121; H. Ogle, Royal Letters Addressed to Oxford (London, 1892), 158-68.

11 VCH Cambridgeshire, vol. III (London, 1959), 33, 192; Maitland, Township and Borough, 91.

12 Beckett, City Status, 14-16.

13 TNA PC 1/13/80; Beckett, City Status, 16.

${ }^{14}$ D. Defoe, A Tour through the Whole Island of Great Britain (London, 1926 edn), vol. I, 267. 
fame to the place. ${ }^{\prime 15}$ Bath had rather tenuously hung on to city status after losing out to Wells in the diocesan stakes, by claiming a royal foundation myth with a Roman heritage ${ }^{16}$ But Defoe's incredulity with the situation over towns and cities climaxed when he came to Manchester, 'the greatest mere village in England', a description he offered because it had no city charter or corporation, but 50,000 or more people:

you have here then an open village, which is greater and more populous than many, nay, than most cities in England, not York, Lincoln, Chester, Salisbury, Winchester, Worcester, Gloucester, no not Norwich itself, can come up to it; and for lesser cities, two or three put together, would not equal it, such as Peterborough, Ely, and Carlisle, or such as Bath, Wells and Lichfield, and the like of some others. ${ }^{17}$

Defoe's underlying viewpoint that a large place should be a city was reflected in the definition offered by Dr Samuel Johnson in his Dictionary of 1755. He split the term into two: 'a large collection of houses and inhabitants'; and 'a town corporate, that hath a bishop and a cathedral church'. Contemporaries recognized a city as being a large place, and accepted that it also had a legal definition in respect of a cathedral. ${ }^{18}$

Since petitions to the monarch for city status seem to have ceased in 1613 , and no new dioceses were created until the nineteenth century, it followed that no city charters were granted. When new sees were created in the nineteenth century, they were not necessarily in the largest towns, but in towns which had an appropriate high-status church which could be consecrated as a cathedral. ${ }^{19}$ This helps to explain why the first new bishopric in Yorkshire in 1836 was in Ripon, not in Leeds, Sheffield or any other of the great industrial towns of the county. Manchester was next in 1853, but it had the appropriate ecclesiastical architecture as well as being one of the great industrial towns of Victorian England. There, the process stalled until St Albans and Truro were created cities in 1876 when they became the sees of new dioceses. Liverpool and Newcastle followed in 1881 and 1882 and, like Manchester, were never likely to provoke raised eyebrows, but the next two new sees were Southwell in 1884, and Wakefield in 1888. With a population of 3,700, Southwell was little more than a village, while Wakefield was significantly smaller than both Leeds and Bradford which were within the new diocese. Wakefield became a city, but Southwell, lacking a corporation, was the first non-diocesan see town not to be given city status. ${ }^{20}$

15 Ibid., vol. II, 33.

${ }^{16}$ Ex inf. Dr Peter Fleming.

17 Defoe, Tour, vol. II, 261-2.

18 johnsonsdictionaryonline.com/?page_id=7070\&i=381 (accessed 13 Nov. 2012).

19 P.S. Morrish, 'Parish-church cathedrals, 1836-1921: some problems and their solution', Journal of Ecclesiastical History, 49 (1998), 434-64.

20 P.S. Morrish, 'County and urban dioceses', Journal of Ecclesiastical History, 26 (1975), 279300; idem, 'Leeds and the dismemberment of the diocese of Ripon', Proceedings of the Thoresby Society, 2nd ser., 4 (1994), 62-97; J. Beckett, 'City status in the nineteenth century: Southwell and Nottingham, 1884-97', Transactions of the Thoroton Society, 103 (1999), 149-58. 
Table 2: Cities as a percentage of large towns

\begin{tabular}{lcl}
\hline \hline Date & Cities in top 20 towns by size & Percentage \\
\hline 1086 & 7 & 35 \\
1334 & 8 & 40 \\
1520 & 8 & 40 \\
1600 & 12 & 60 \\
1799 & 10 & 50 \\
1801 & 5 & 25 \\
1841 & 4 & 20 \\
1881 & 3 & 15 \\
1901 & 11 & 55 \\
1951 & 16 & 80 \\
2002 & 17 & 85 \\
\hline \hline
\end{tabular}

In the meantime, towns lacking Anglican cathedrals had no formal means of acquiring city status, apparently because the principle of a petition to the monarch had either been forgotten or was not considered appropriate. The anomalous position that this created is clear from Table 2. In 1600, 12 of the 20 largest English towns were cities (60 per cent). By 1700, 10 of the 20 largest English towns were cities (50 per cent). By 1801, just 5 of the largest 20 towns were cities ( 25 per cent), and by 1841, 4 out of 20 (20 per cent). The top 20 towns in 1881 included 17 towns with populations of 100,000 or more, which did not have city charters, and mostly these were in the heartlands of the industrial revolution. Cities such as Lichfield and Hereford, Winchester, Chichester and Salisbury were completely overshadowed. The fact that so many existing cities were outside the heartlands of industrialization, and had been left behind in population terms, was beginning to make the term look outmoded, indeed ridiculous, in the way that it was being used.

It was at this point that the principle of an appeal to the monarch for the conferment of the title was resurrected. This was partly driven by the anomalous position that was developing whereby quite small towns like St Albans were entitled to city status when the existing abbey was turned into a cathedral, while large industrial towns were passed over. It was also driven by other concerns including the growing obsession with civic honours demonstrated in the concern among civic leaders with ritual and identity, which arose partly from visits to industrial towns by Queen Victoria in the 1850s. ${ }^{21}$ Another concern was with the economic impact expressed most openly when in 1882 Newcastle was made a city following

${ }^{21}$ S. Gunn, The Public Culture of the Victorian Middle Class: Ritual and Authority in the English Industrial City 1840-1914 (Manchester, 2000), 164-52; D. Cannadine, 'The transformation of civic ritual in modern Britain: the Colchester Oyster Feast', Past and Present, 94 (1982), 107-30; Beckett, City Status, 29-33. 
the creation of the diocese of Newcastle. In a speech to the town, now city, council on 5 July, the mayor linked the award specifically with wealth: 'I trust it will be a pleasure to every one of us to see the commerce of this city advancing at a very rapid rate. ${ }^{22}$ The possibility that city status would have commercial benefits was not lost on Belfast when in 1887 it applied for a city charter as a Queen Victoria Golden Jubilee civic honour. Given its particular urban background, and its rapid industrial development, Belfast believed it might achieve city status as an honour from the queen, who had visited the town in $1849 .{ }^{23}$ Significantly, the case for making the application was proposed by the president of the Belfast Chamber of Commerce. ${ }^{24}$ The charter was granted in 1888, after Belfast had formally submitted a petition to the queen. ${ }^{25}$

The Belfast case had revived the principle last used in the seventeenth century whereby a town seeking city status could petition the monarch directly. She would pass responsibility for investigating the claim to her ministers (in this case the Home Office), and they in turn would make a recommendation which would require her approval. Birmingham was given city status in 1889, Leeds and Sheffield in 1893 and Bradford, Hull and Nottingham in 1897. To try to prevent this trickle of worthy claimants turning into a flood, the Home Office set a population bar of 300,000. When the pace of urban growth slowed and few, if any, towns were able to cross the bar, the rules were changed (to 250,000 and eventually to 200,000). As a result, the imbalance between urban size and city status was gradually corrected, and by 1951, all of the top 15 towns by population were cities, and 16 of the top 20 (80 per cent) enjoyed the status (Table 2). ${ }^{26}$

The link with royal events was also considered to be important since this was a crown honour. Bradford, Hull and Nottingham were promoted in 1897 as Diamond Jubilee honours. Subsequently, city charters were granted in connection with royal visits (Leicester and Stoke on Trent) ${ }^{27}$ or royal anniversaries (George V's Golden Jubilee in 1937 - Lancaster). ${ }^{28}$ Southampton and Cambridge investigated petitioning for city status as a coronation honour in 1953, and Coventry received a Lord Mayoralty on that occasion. ${ }^{29}$ Clearly, royal events, such as Lancaster's elevation in 1937, depended on a monarch remaining on the throne for a long period

22 Newcastle City Minutes, 1881-82, 306-7.

23 S.J. Connolly, 'Like an old cathedral city: Belfast welcomes Queen Victoria, August 1849', Urban History, 39 (2012), 571-89.

24 TNA HO 45/9774/B1512; Public Record Office of Northern Ireland, Belfast Corporation, Town Minute Books, 1884-87, fol. 627, 1887-90, fol. 246.

25 Belfast News-Letter, 10 Jul., 15 Oct. 1888.

26 Beckett, City Status, 64-6, for the debate about the 300,000 figure.

27 Beckett, 'Leicester becomes a city', 151-62; Staffordshire Sentinel, 5 Jun. 1925; Times, 6, 8 Jun. 1925; J. Stobart, 'Identity, competition and place promotion in the five towns', Urban History, 30 (2003), 163-82.

28 J. Beckett, 'Lancaster becomes a city, 1937', Transactions of the Historic Society of Lancashire and Cheshire, 157 (2008), 149-56.

29 TNA HO 286/62. 
of time, and in the meantime dissatisfied towns submitted petitions more in hope than expectation. Southampton was promoted in 1964, despite an argument as to whether it really did have a population of 200,000. Swansea was raised to city status in conjunction with the investiture of Prince Charles as prince of Wales in 1969.30

By 1977, when the queen was due to celebrate her Silver Jubilee, the Home Office had become concerned that it would be buried under an avalanche of city status applications. It decided to identify potential candidates, and to assess their suitability. Derby was promoted, but on a statistical anomaly - it had become the largest non-city as a result of the local government boundary reforms introduced in 1974, overtaking Sunderland in the race for city status on a technicality. ${ }^{31}$ The queen reached her fortieth anniversary on the throne in 1992, when the first full-scale competition was introduced, and attracted 20 applicants. The route to city status was now via a beauty parade. From simply presenting a petition to the crown, potential cities had to present their case, to talk about new investment and why they, rather than any of the others, should be promoted. Sunderland won. ${ }^{32}$

A competition was also introduced in 1992 for a Lord Mayoralty. Just as there is a long-held myth that a city must have a cathedral, so there is a similar mythical view that a city automatically has a lord mayor. In fact, the two awards have been made together just once, for Cardiff in 1905. A competition meant that existing cities, many of them very small, could compete for a title. Nine towns applied and Chester was successful.

The success of this competition went slightly to the government's collective head and, unable to wait until 2002 when the queen would celebrate her Golden Jubilee, a Millennium competition was announced by New Labour. The Millennium was a cause for celebration but it was in no sense a royal event. Whereas the 1992 competition had been limited to English towns, this time the whole of the United Kingdom was involved. Twenty-seven English, four Scottish, six Welsh and two Northern Irish towns applied, and they spent a good deal of money on glossy brochures, videos and other promotional material: Ipswich even hired a special train to convey its application to London. Supposedly, this was a competition for one promotion, but that seemed too constricting, so Brighton and Hove and Wolverhampton were raised to city status, and Inverness was added to placate the Scots. ${ }^{33}$

With the Millennium competition out of the way, the government could promote a further contest two years later for the queen's Golden Jubilee. In 2002, 25 English towns applied, 6 Welsh, 4 Scottish and 6 from Northern

${ }^{30}$ J. Beckett, 'City status for Swansea', Welsh History Review, 21 (Jun. 2003), 129-47.

31 J. Beckett, 'Derby's quest for city status', Derbyshire Archaeological Journal, 128 (2008), 13645.

32 Beckett, City Status, 128-33.

33 Ibid., 141-61. 
Ireland. To avoid any accusation that the judgment was made purely on the grounds of size, Preston was promoted, while to ensure political balance, Newport, Stirling and both Lisburn (a Unionist stronghold) and Newry (a nationalist stronghold) were promoted. Exeter won the Lord Mayoralty competition. ${ }^{34}$

With no equivalent of the Millennium, and no appropriate royal event, the next opportunity for a competition was delayed until 2012, the queen's Diamond Jubilee. On 5 January 2010, Lord Mandelson, in a statement to the House of Lords, provided outline arrangements for the celebrations being planned for the Diamond Jubilee in 2012. They were to include national competitions for city status and a Lord Mayoralty (Lord Provostship in the event of the award going to a Scottish city). ${ }^{35}$ Mandelson also announced that the Diamond Jubilee arrangements would be made via the Department of Culture, Media and Sport (DCMS). ${ }^{36}$ Bids had to be submitted by 27 May 2011 to DCMS - the awards had been downgraded from the work of the Home Office, to the Ministry of Justice in 2002, and now to DCMS.

The government did at least suggest some entry guidelines for wouldbe cities to follow. Any local authority, whether district, borough, parish, town, community or unitary council, from any area of the United Kingdom, 'which considers that its area deserved to be granted the rare honour of city status' was invited to apply. A standard size and format was laid down for entries 'to help local authorities minimise the expense of entering the competitions and to provide the Government with a fair basis for comparison and assessment of the entries received' - Milton Keynes subsequently claimed that its unsuccessful bid cost only $£ 116 !^{37}$

Candidates needed to show that they were 'vibrant, welcoming communities with interesting histories and distinct identities'. Bids had to focus on why the place deserved city status with particular reference to its age, distinct identity, history, traditions, famous residents and any associations with royalty and other particularly distinctive features. Applicants had to provide a profile of the place, including statistics, 50 photographs of permanent features, 2 maps showing the town centre and the main tourist and leisure and entertainment sites, green spaces accessible to the public and transport routes. Brief details of local governance were to be supplied, together with 'an account of the range, variety and appeal of community and "interest" groups based in the area'. ${ }^{38}$ The same range of information was required also for the Lord

34 Ibid., 163-77.

35 www.bis.gov.uk/jubilee (accessed 16 Feb. 2010).

36 The Guardian online, 6 Jan. 2010: www.guardian.co.uk/politics/2010/jan/06 (accessed 16 Jan. 2010).

37 www.culture.gov.uk/what_we_do/honours/7610.aspx (accessed 5 Mar. 2012); Milton Keynes Citizen, website, 15 Mar. 2012.

38 'Diamond Jubilee Civic Honours Competitions Entry Guidelines', published on the DCMS website. 
Table 3: Applicants for city status 2012

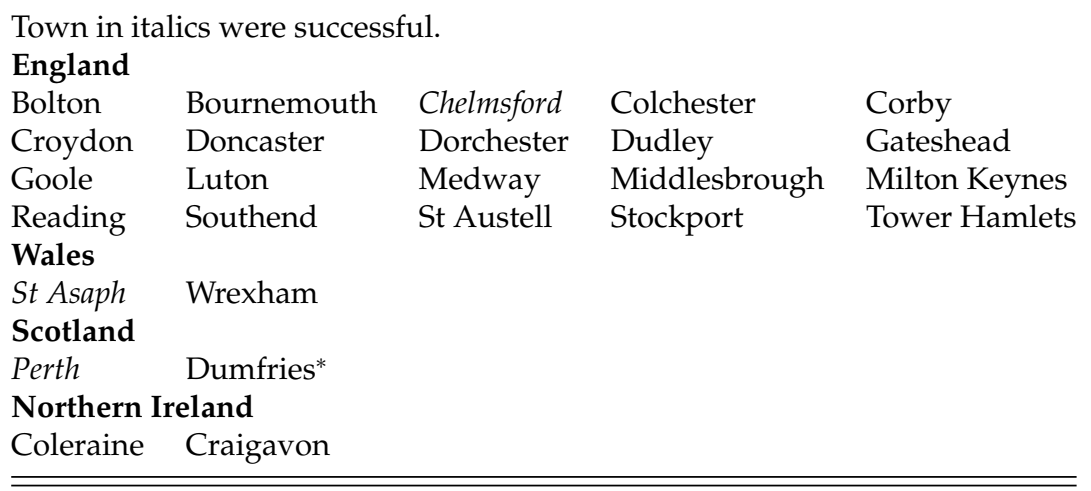

*Application rejected as invalid, www.bbc.co.uk/news/uk-scotland-southscotland-13808882 (accessed 12 Nov. 2012).

Mayoralty competition. The only difference was that Millennium and Golden Jubilee cities were not allowed to enter this competition.

There was no more transparency than in the past. As the DCMS website explained, 'neither city status nor Lord Mayoralty has ever been a right to be claimed by places fulfilling a list of criteria, as this might devalue the honour'. Instead, the government published guidelines 'on the format and contents of entries' describing 'information which the Government has found useful in reaching a decision, but they do not set out formal criteria'. The guidelines did at least include information designed 'to help local authorities minimise the expense of entering the competitions'. The closing date was 27 May 2011. ${ }^{39}$

Despite these unpromising beginnings, the applications came flooding in, although significantly fewer than in 2002: 26 - although one was disallowed - rather than 41 (Table 3). According to the government, the applications were then subjected to a rigorous process of review and discussion. They were assessed 'in the round' and on their individual merits. There is no reason to doubt that this was the case, but the gist of the matter came in the usual disclaimer: 'As a Royal prerogative matter relating to honours the process will remain confidential, as will Ministers' conclusions. The Queen's decision, made on Ministerial advice, is final and no reasons will be given for applicants' success or failure in the competitions. ${ }^{40}$

Who was involved? The deputy prime minister was assisted by the minister for political and constitutional reform, Mark Harper, the secretary of state for culture, media and sport, the secretaries of state for Scotland, Wales and Northern Ireland and the secretary of state for communities and

39 Ibid.

40 Ibid. 
local government. How they made their decisions is not known, reflecting similar opaqueness across the whole honours system. ${ }^{41}$

Nick Clegg announced the competition results on 14 March 2012. Chelmsford, Essex, won the competition for England, St Asaph for Wales and Perth for Scotland. To maintain equity through the United Kingdom, the Lord Mayoralty went to Armagh, Northern Ireland. It was a neat recognition of all parts of the United Kingdom in Diamond Jubilee year, and reflected principles similar to those applied in 2002, even though, as in earlier competitions, the original announcement had suggested that only one city would be made.

Chelmsford became the first city in Essex. It is also the county capital and, since 1914, a cathedral town. It first applied for city status in 1914, and had regularly been in the competitions since 1992. Even so, the local football team was caught on the hop. For 74 years it has been known as Chelmsford City, no one apparently having realized it was not entitled to such as name. ${ }^{42}$

Perth was the only serious candidate in Scotland. It claimed to have been a city until local government reforms in 1974, and had been second city of Scotland since 1437. Even after it lost city status after 1974, it continued to be known as the 'Fair City', a title derived from Sir Walter Scott's 1828 story of the Fair Maid of Perth. Perth had also recently celebrated its 800th anniversary. ${ }^{43}$

It was St Asaph which caught the imagination, and garnered most of the, admittedly sparse, newspaper headlines. The 1992 competition won by Sunderland had been limited to English towns, but Newport and St Asaph in Wales and Armagh in Northern Ireland had also been proposed. Newport was turned down, although it was subsequently promoted in 2002. The cases of St David's and Armagh were more problematic. Both were considered too small in 1992 to succeed under the usual considerations (St David's had a population of only 1,700). Armagh had certainly applied several times in the past for what it saw as a restoration. ${ }^{44}$ Both entered the 1992 competition, but both were turned down on the basis of size. However, in 1994, city status was conferred on the two towns, at the express wish of the queen, 'in recognition of their important Christian heritage and their status as cities until the last century'.$^{45}$

This rather neat arrangement put St Asaph's nose firmly out of joint. Despite being a cathedral town, no evidence was found in 1992 that it had ever been a city by ancient prescriptive right. The local council was sure it had been, and even presented a petition to the queen. They entered the competitions in 2000 and 2002, applying for 're-admission' as a city, and

41 www.culture.gov.uk/what_we_do/honours/7610.aspx (accessed 5 Mar. 2012).

42 BBC News website/Essex, 15 Mar. 2012.

43 Scottish Daily Record website, 15 Mar. 2012.

44 The earlier Armagh applications are in TNA HO 286/38, 39.

45 Times, 8 Jul. 1994; pers. comm. from the dean of St David's, Very Revd J. Wyn Evans, 29 Sep. 1999; pers. comm. from the Home Office, 11 Jun. 1999; Beckett, City Status, 133-4. 
failed both times, ${ }^{46}$ but with Wrexham as the only competition in $2012 \mathrm{St}$ Asaph succeeded, despite a population of just 3,400. ${ }^{47}$

By awarding the Lord Mayoralty to Armagh the government ensured that each part of the United Kingdom received a civic honour, and at the same time it redressed the balance upset in 2002 by the promotion of two towns to city status in Northern Ireland. What is perhaps most interesting in the decision making was the return, or so it seemed, to an older principle that a candidate for city status needed a cathedral (all four new cities already had them) and that a Lord Mayoralty might follow only after a suitable time lag - the competition rules specifically excluded new cities made in 2000 and 2002.

On the announcement of these promotions, much self-congratulation occurred among the successful candidates, and many sour grapes came from those places which did not succeed: in the words of Sir Bob Russell, Colchester MP, 'what the criteria was for an anonymous group of officials used to choose Chelmsford above other applicants, including Colchester, is something of a mystery. I am sure that other unsuccessful towns will be scratching their collective heads as well. ${ }^{48}$ As Lib-Dem MP for Colchester, he must have been particularly annoyed to see Chelmsford win, with a Conservative MP, and the official announcement made by his own party leader. The Reading Chronicle was apoplectic, complaining that Reading had missed out 'for the third time - defying bookies odds and dashing hopes across the town'. ${ }^{49}$

Of course, there were plenty of people willing to be quoted, saying it would make no difference, but there was clearly disappointment. ${ }^{50}$ Tower Hamlets, which had applied for the first time, was probably neither surprised not greatly upset since Croydon also failed again, demonstrating the problems for London boroughs in entering such competitions. ${ }^{51} \mathrm{St}$ Austell, in the competition for the first time, can hardly have been surprised that it was not the winner.

So what did success and failure mean? Answering questions like this takes us back to the heart of the issue identified by the mayor of Newcastle in 1882, competitive edge. Do cities do better than non-cities? The simple answer is that it is perceived to be the case, both historically, ${ }^{52}$ and currently. The Local Government Act (1972), and its Scottish equivalent, allowed local authorities to raise a small rate to be spent on purposes which would

${ }^{46}$ Beckett, City Status, 134-5.

47 Times, 15 Mar. 2012; Guardian, 15 Mar. 2012; Independent website, 14 Mar. 2012; Daily Post North Wales, 15 Mar. 2012.

48 East Anglian Daily Times website, 14 Mar. 2012; Colchester Daily Gazette website, 14 Mar. 2012.

49 Reading Chronicle, 15 Mar. 2012.

50 Reading Chronicle, 15 Mar. 2012; getreading, 16 Mar. 2012.

51 Economist, 28 January 2012; www.wharf.co.uk (accessed 14 Mar. 2012).

52 Stobart, 'Identity, competition and place promotion', 163-82; P.J. Larkham and K.D. Lilley, 'Plans, planners and city images: place promotion and civic boosterism in British reconstruction planning', Urban History, 30 (2003), 183-205. 
benefit the locality. Many towns took up this opportunity, usually with the intention of promoting inward investment at a time when their economies were undergoing change. ${ }^{53}$ In 1989, local authorities were empowered to spend money directly on boosterism. ${ }^{54}$ They now had the wherewithal to consider the image that they presented to the wider world, and how this might be improved, and they did not hesitate: in 1977, 43 per cent of local authorities produced a guide, but this proportion had risen to 84 per cent by $1992 .{ }^{55}$ It is hardly surprising that city status was seen as a form of boosterism, nor that 20 English towns entered the competition in 1992. Achieving city status was a way of announcing to an international audience that here was an important place with which they should be doing business. ${ }^{56}$

Whether or not this was actually true was beside the point, although the subsequent evidence is mixed, partly because winners need to convince their electorates that the effort has been worthwhile, and that city status is a catalyst for regeneration and future success. Colin Anderson, council leader in Sunderland, encouraged entrants in the Millennium and Golden Jubilee competitions because, he argued, the new city 'has boomed since 1992 and we have really made a big play on the fact that we are not a town any more ... City status gave us recognition. ${ }^{57}$ Steve Musson has argued that the new cities of 2000 and 2002, with the exception of Wolverhampton, outperformed their regional counterparts in terms of increasing investment and reducing unemployment. ${ }^{58}$ Stephen Parkinson, who led Preston's successful bid in 2002, argued that city status served to put Preston on the map: 'we have joined an elite club. You are recognised internationally and nationally as a place that means business. ${ }^{\prime 59}$ Less quantifiable outcomes include international exposure, and the general buzz of local excitement as feelings of pride, community and nationalism are generated by a symbolic event such as the competition for, and grant of, city status - quite apart from changing the road signs. ${ }^{60}$

Losers have often justified their defeat in terms of what might have been. Medway council believed being recognized as a city, rather than a series of towns (Rochester, Gillingham, Strood and Chatham), would

53 S. Ward, Selling Places: The Marketing and Promotion of Towns and Cities, 1850-2000 (London, 1998), 187-8; C. Philo and G. Kearns (eds.), Selling Places: The City as Cultural Capital, Past and Present (Oxford, 1993).

54 A. Eisenschitz and J. Gough, The Politics of Local Economic Policy: The Problems and Possibilities of Local Initiative (Basingstoke, 1993).

55 T. Hall, Urban Geography, 2nd edn (London, 2001), 123.

${ }^{56}$ Beckett, City Status, 127-30.

57 Quoted in 'People power will fuel bid to be city', hhtp:/ / thisislancashire.co.uk (accessed 25 Sep. 2001); Beckett, City Status, 182-3.

58 www.reading.ac.uk/about/newsandevents/releases/PR437981.aspx (accessed 14 Mar. 2012); www.bbc.co.uk/news/magazine-13841482 (accessed 22 Jun. 2011).

59 www.bbc.co.uk/news/magazine-13841482.

${ }^{60} \mathrm{G}$. Waitt, 'The Olympic spirit and civic boosterism: the Sydney 2000 Olympics', Tourism Geographies, 3 (2001), 249-78; Beckett, City Status, 148, on the way applicants for city status in 2000 involved their communities in the bids. 
have brought investment and jobs to the area. ${ }^{61}$ Dudley council said that success in the competition would have generated economic investment from businesses across the globe. ${ }^{62}$ How they could hope to know this is unclear, except as a general expectation, but there is a germ of truth in it for the simple reason that post-industrial world towns and cities have taken to re-inventing themselves as centres of business services such as finance, computer software, advertising and other professional, officebased, activities. ${ }^{63}$ One of the supporting documents for Sunderland's city status application in 1992 was a leaflet entitled 'Sunderland Investor's Guide, Next Generation Industries'.

Whitehall has also seen economic advancement as an outcome, with competition guidelines raising questions about tourism and retailing, shops and other attractions, to see how well would-be cities are adapting to the new environment, perhaps by investing in cultural capital such as museums, art galleries, theatres and concert halls, sports stadia and leisure centres. ${ }^{64}$ Within this adaptation has been a renewed emphasis on historic significance and tourism, hence some of the other competition questions. ${ }^{65}$ Documents in the Sunderland pack in 1992 included A Visitor's Guide to Wearside, and Sunderland 1991 Holiday Guide. To counteract nostalgia, competitors also have to point to initiatives such as new buildings of striking design and high-quality finishing. Public art and night life are among other activities which are boosted in similar manner, including restaurants, night clubs and entertainments. Watersides (both former docks and canals) also have to be developed to clear away poor quality areas, but to bring in their place new forms of living and entertainment. The government was really looking to see which towns were achieving most.

How can the 2012 competition be summed up? Competitions were originally introduced in 1992 for English towns, but the admission of Scotland, Wales and Northern Ireland has changed the ground rules and, arguably, given English towns a distinct disadvantage. Bolton, Colchester, Croydon, Doncaster, Luton, Medway, Middlesbrough, Milton Keynes, Reading and Stockport all applied unsuccessfully in both 2002 and 2012. Several had applied also in 1992, perhaps most notably the bookmaker's favourite, Reading. Blackburn, Guildford, Ipswich, Northampton and Shrewsbury all applied in 1992, 2000 and 2002 but failed to stay the course

61 BBC News website: Kent, 14 Mar. 2012.

62 Dudley Express and Star website, 14 Mar. 2012; Birmingham Post.net, 15 Mar. 2012.

63 C.M. Law, Urban Tourism: Attracting Visitors to Large Cities (London, 1993); Larkham and Lilley, 'Plans, planners and city images'.

${ }^{64}$ F. Bianchini and M. Parkinson (eds.), Cultural Policy and Urban Regeneration: The West European Experience (Manchester, 1993); M. Boyle, 'Civic boosterism in the politics of local economic development - "institutional positions" and "strategic orientations" in the consumption of hallmark events', Environment and Planning, A 29(11) (1997), 1975-97.

65 G.J. Ashworth and J.E. Tunbridge, The Tourist-Historic City (Chichester, 1990); Hall, Urban Geography, 127-8. 
Table 4: United Kingdom cities in 2012

\begin{tabular}{llll}
\hline \hline England & & & \\
Bath & Durham & Manchester & Salisbury \\
Birmingham & Ely & Newcastle-upon-Tyne & Sheffield \\
Bradford & Exeter & Norwich & Southampton \\
Brighton \& Hove & Gloucester & Nottingham & Stoke-on-Trent \\
Bristol & Hereford & Oxford & Sunderland \\
Cambridge & Hull & Peterborough & Truro \\
Carlisle & Lancaster & Plymouth & Wakefield \\
Canterbury & Leeds & Portsmouth & Wells \\
Chelmsford & Leicester & Preston & Westminster \\
Chester & Lichfield & Ripon & Winchester \\
Chichester & Lincoln & Rochester* & Wolverhampton \\
Coventry & Liverpool & St Albans & Worcester \\
Derby & London & Salford & York \\
Scotland & & & Stirling \\
Aberdeen & Edinburgh & Inverness & \\
Dundee & Glasgow & Perth & \\
Wales & & & \\
Bangor & Newport & St David's & \\
Cardiff & St Asaph & Swansea & \\
Northern Ireland & & & \\
Armagh & Lisburn & Newry & \\
Belfast & Londonderry & & \\
\hline \hline
\end{tabular}

* Rochester is included in this list although technically it lost the status at local government reorganization in 1996, and has not subsequently been able to win it back. Government lists normally exclude it.

Source: Home Office list, 1999 with subsequent additions.

to 2012. Some towns dropped out between 2000 and 2002, but others joined in, while some dropped out between 2002 and 2012 with others joining in. Altogether, 16 substantial English towns have applied three or four times in the past 20 years for city status without success, watching in the meantime places like St David's and St Asaph, Armagh, Lisburn and Newry overtaking them (Table 4).

City status is, in reality, a town hall honour. There is actually nothing to prevent towns from calling themselves cities, changing the headed notepaper, the website and the sign boards, and challenging the government to do something about it. Elgin, in Scotland, calls itself a city; Dunfermline quit entering the competitions, changed the sign boards and now calls itself a city; St Asaph called itself a cathedral city until it gained promotion (and so can be a city without the prefix 'cathedral' which had no constitutional meaning); Milton Keynes used to, but no longer does, call 
itself a city; and Medway has been rebuked by the Advertising Standards Agency for calling itself the City of Medway. ${ }^{66}$

Surprisingly, perhaps, the town hall movers and shakers remain reluctant to use the term 'city' unless they have the piece of parchment, but no one else seems too concerned. The Centre for Cities, an independent, non-partisan research and policy institute 'committed to improving the economic performance of UK cities', seems wholly unperturbed by such nit-picking. It utilizes data for 'primary urban areas' in its analysis, and includes 25 English towns which do not have city charters among the 64 urban areas that it covers. Perhaps significantly, all eight of the places it analyses in Scotland, Wales and Northern Ireland do have city charters, confirming the suggestion that it is English towns which have missed out on this particular form of civic boosterism. ${ }^{67}$

If there are real benefits to city status, including economic benefits, the only reason why towns are not freed from the constraints of being boroughs and towns rather than cities has to be related to political patronage: Labour Preston succeeded in 2002, and Conservative Chelmsford in 2012. Simon Burns, Conservative MP for Chelmsford, was quoted on the BBC website as being 'delighted' to hear that Chelmsford would become the first city in Essex. A decade previously, Burns had suggested in the Commons that New Labour ministers were 'engaged in a cynical political fix' to give the status only to towns in Labour strongholds, hence Preston's promotion in 2002. The Coalition seemingly took the first opportunity to 'fix' promotion for Burns' Conservative Chelmsford, and in turn Burns happily took the credit. ${ }^{68}$

Perhaps this is pressing the issue too far. Technically, the term still refers to a grant from the monarch on receipt of a petition, just as it did in the days of King James I, but the way this is manipulated and the use of the term 'city' has changed out of all recognition. What began as a royal honour graciously bestowed, is now a title sought primarily to help to boost the standing and image of the new city or cities, nationally and particularly internationally. Hence, the competitive edge sought by individual entrants, and the efforts of public relations officers to 'sell' their town as a city. No doubt when the next city status competition is held, the leaders of Chelmsford, Perth and St Asaph will be wheeled out to say just how successful their cities have been since they were granted the title.

\footnotetext{
${ }^{66}$ www.asa.org.uk/Rulings/Adjudications/2011/3/Medway-Council/TF_ADJ_49924. aspx (accessed 12 Nov. 2012).

67 www.centreforcities.org/puas (accessed 13 Nov. 2012).

68 Guardian, 20 Mar. 2012, p. 35.
} 